\title{
FURTHER VARIATIONS OF A TEXT BY VALLEJO
}

Robert Crum

I will die in Omaha in a heat wave, on a day when the moon is out, when the thunderheads mount high above the horizon, and do not rain, on a day like any day on the calendar hung on the back wall of the Goodyear Garage on which there is a picture of a woman with large breasts caressing, with her slender fingers, the smooth, shiny, black treads of the company's latest radial tire.

It will be a Saturday like today, because today, Saturday, I can smell, on this thick breeze from the south, the stockyards. It's an odor not quite fetid, not quite sweet, as I imagine death must be to those not quite happy to be in Omaha, in a heat wave, on a Saturday. And I think it will be a Saturday because today the butchers' wives have packed the Safeway, and they stand talking beside their cars in the parking lot, their voices shrill above the traffic, and even when the traffic is drowned out by a B-52 bomber taking off from SAC, they keep talking as if nothing happened.

Robert Crum is dead. One Saturday the tissue-thin moon drifted behind the Mutual of Omaha Building, and there came a great lowing from the stockyards. The bourboned butchers stumbled from the bars into the ripe air, their wives were still talking, and the pilot of the B-52 mumbled to himself his secret destination, and the mechanic, back in the Goodyear Garage where it is cool and moist and the smell of lubricant is strong, winked once at the girl on the calendar, and from the bald retread yanked the pressure stem. 